\title{
Association between BRAFV600 mutation and the clinicopathological features in incidental papillary thyroid microcarcinoma: A single-center study in Turkish patients
}

\author{
(1) Havva Sezer, ${ }^{1}$ (D) Nihal Uren, ${ }^{2}$ (1) Dilek Yazici ${ }^{1}$ \\ ${ }^{1}$ Department of Endocrinology and Metabolism, Koc University Faculty of Medicine, Istanbul, Turkey \\ ${ }^{2}$ Department of Medical Biology and Genetics, Kocaeli University Faculty of Medicine, Kocaeli, Turkey
}

\begin{abstract}
OBJECTIVE: In this study, we evaluated the influences of BRAFV00E mutation on clinicopathological features in incidentally found papillary thyroid microcarcinomas (PTMCs).

METHODS: This retrospective cohort study included 72 patients with PTMC who underwent surgery from 2008 to 2012. The mean follow-up of the whole cohort was three years. DNA was isolated using QIAamp DNA formalin-fixed, paraffin-embedded (FFPE) tissue kit. BRAF gene was amplified by the polymerase chain reaction-restriction fragment length (PCR-RFL) polymorphism method with the following primers. The clinicopathologic features (age, gender, histologic subtype, tumor size, presence of tumor capsule, bilaterality, multifocality, extrathyroidal extension (ETE), thyroid capsular invasion, presence of Hashimoto's thyroiditis, lymph node metastasis (LNM) and distant metastasis) were compared between the BRAF (+) and BRAF (-) patient groups.

RESULTS: BRAFV600 mutation was detected in 30 of the 72 patients (41.6\%). The presence of the mutation was statistically significantly associated with classic variant $(p=0.046)$, invasion of thyroid capsule $(p=0.002)$ and absence of tumor capsule $(\mathrm{p}=0.003)$.

CONCLUSION: Although incidental PTMCs positive for the BRAF'V600 mutation had more invasive behavior, the presence of the mutation was not associated with recurrences within three years of follow-up.

Keywords: BRAFr600E; clinicopathological features; incidental; papillary thyroid microcarcinoma.

Cite this article as: Sezer H, Uren N, Yazici D. Association between BRAF ${ }^{1600 E}$ mutation and the clinicopathological features in incidental papillary thyroid microcarcinoma: A single-center study in Turkish patients. North Clin Istanb 2020;7(4):321-328.
\end{abstract}

$\mathrm{D}$ ifferentiated thyroid carcinomas are the most common endocrine malignancy with good prognosis and a long-term survival [1]. Over the past decades, the incidence of papillary thyroid carcinoma (PTC) has increased worldwide [2]. The recent advances in ultrasonographic imaging and ultrasound-guided fine-needle aspiration biopsy (FNAB) have allowed more PTMCs to be discovered [3]. Approximately $50 \%$ of the new PTCs are PTMCs [4]. PTMC is a type of PTC that is defined by the World Health Organization as having a maximum diameter of $1.0 \mathrm{~cm}$ or less [5]. Many studies support that PTMCs are mostly incidental findings in surgeries for other pathologies nonrelated to thyroid malignancy $[6$, $7]$. Incidentally discovered that thyroid cancers are less aggressive compared to clinically apparent thyroid cancers $[6,7]$. The clinical significance of PTMC is still unclear. 
PTMC generally has an excellent prognosis and is rarely associated with local or distant metastasis [8-10]. On the other hand, PTMC may progress with a significant recurrence rate and even mortality in some patients [1113]. A study reported that cancer-related mortality rate was $1.0 \%$, the distant metastasis rate was $2.5 \%$, and the lymph node recurrence rate was $5 \%$ in PTMCs [14]. The presence of high-risk clinicopathological factors, including ETE, LNM, and high TNM stages, are classically known to be associated with a poor prognosis [15-18]. There is no consensus to support either a more conservative approach or a more aggressive treatment for this patient group. In recent studies, patients with cytologicallyconfirmed PTMC were monitored by regular ultrasound and were performed surgery only when the PTMC exhibited progression or spread [19-22]. Their results have shown that $>90 \%$ of PTMCs did not have progress with time under the non-surgical approach; none of the patients developed distant metastasis or died [19-22].

Many genetic alterations were associated with the development of follicular cell-derived thyroid cancer [1]. The activating mutations in some genes play main role in the pathogenesis of thyroid cancer and cause a malignant transformation in thyroid follicular cells. The Btype Raf kinase (BRAF) is one of the members of the RAF gene family and plays a role in the pathogenesis of the PTC. BRAF gene encodes a protein that is in charge of the mitogen-activated protein kinase (MAPK) signaling pathway and it has a serine/threonine kinase activity [23]. The MAPK signaling pathway is a regulator of numerous cellular processes, including division, proliferation, differentiation, adhesion, migration and apoptosis [24]. The BRAF mutation induces aberrant activation of the MAPK pathway. The T1799A somatic point mutation results in a valine-to-glutamic acid switch at codon 600 (BRAF ${ }^{\mathrm{V} 600 \mathrm{E}}$ ), which is located on chromosome $7 \mathrm{q} 24$ in exon 15. The BRAF activated point mutation is the most common genetic alteration, which has been determined in different series at a rate of $20-52 \%$ in PTMCs [25]. In the many recent studies, BRAF mutation is associated with recurrence, poor prognosis, LNM, ETE and aggressiveness in patients with PTC [26-30]. Its prognostic value is unclear in PTMCs. The BRAF mutation-induced molecular changes [(suppressing many tumor-suppressor genes, increasing pro-tumor and proangiogenetic molecules, reducing differentiation of the tumor, and radioactive iodine (RAI) retention capability)] are likely to be responsible for PTMC aggressiveness $[4,11,25,26]$. However, another study showed

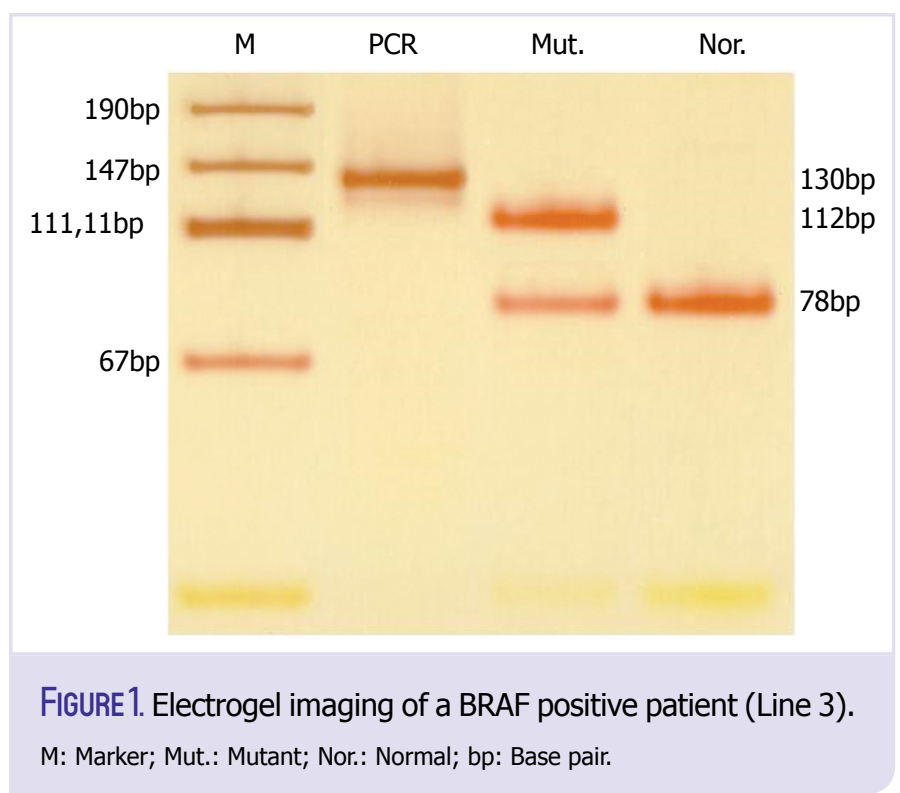

no significant correlation between BRAF mutation and aggressive behavior [31]. American Thyroid Association (ATA) 2015 Guideline included BRAF ${ }^{\mathrm{V} 600 \mathrm{E}}$ mutation into the risk group of the recurrence in PTMCs.

Turkey is in a region that is with an increased risk of thyroid cancer. Iodine deficiency and being in close proximity to the Chernobyl accident have increased the incidence of thyroid cancer in Turkey [32]. There are data determining the aggressiveness of PTMCs with BRAF mutation in Turkish patients [28]. One study found a significant association between LNM and BRAF mutation [28], although conflicting findings were reported in another study [33]. Our study aimed to evaluate the influences of BRAF mutation on clinicopathological features in incidental microcarcinomas in a Turkish population.

\section{MATERIALS AND METHODS}

All the patients included in this study were diagnosed with PTMC between 2008 and 2012. This study was a retrospective study, and all procedures in this study were approved by our hospital's ethics committee. Follow-up data information was obtained from hospital records. The patients were followed up for at least one year. Seventy-two tumor samples from 72 patients were studied. If more than one PTMC was present, the largest tumor was considered for this study. The tumors were clinically asymptomatic. Thyroidectomy was performed on 26 of 72 patients $(36.1 \%)$ due to benign thyroid disease and PTMC was diagnosed after thyroidectomy. In the rest of the group, in 46 patients $(63.8 \%)$, FNAB was performed 
according to the suspicious features of the nodules in thyroid ultrasonography and PTMC was diagnosed before surgery. Demographic factors (age and gender), clinicopathological factors, including tumor size, multifocality of the tumor, bilaterality, presence of thyroid capsular invasion, presence of tumor capsule, ETE, presence of Hashimoto's thyroiditis, LNM, distant metastasis and presence of BRAF mutation, were included into a risk analysis of these patients. We reviewed the preoperative thyroid-stimulating hormone (TSH). Tumor pathology in the surgical material was identified with an experienced pathologist. The genomic DNA was extracted from the paraffin-embedded tumor blocks $(5 \mu \mathrm{m}$ thick sections with a confirmed tumor). As for the DNA isolation, QIAamp (Qiagen) DNA FFPE tissue kit was used.

\section{DNA Isolation}

The paraffin was removed, $1.25 \mathrm{ml}$ of xylol was added and centrifuged. Xylol was discharged, $1 \mathrm{ml}$ of $100 \%$ ethanol was added and centrifuged. The ethanol was discharged, and the tubes were put into the heat block for evaporation of the remaining ethanol. One hundred and eighty $\mu \mathrm{l}$ tissue lysis buffer and $20 \mu \mathrm{l}$ proteinase $\mathrm{K}$ enzyme were added. The tubes were kept at $56{ }^{\circ} \mathrm{C}$ and at $90{ }^{\circ} \mathrm{C}$. Two hundred $\mu \mathrm{l}$ lysis buffer and $200 \mu \mathrm{l}$ of $100 \%$ ethanol were added and centrifuged. The samples were kept at $+4{ }^{\circ} \mathrm{C}$ and centrifuged. Five hundred $\mu \mathrm{l}$ washing buffer 1 was added and centrifuged. Five hundred $\mu$ l washing buffer 2 was added and centrifuged. The upper filtered part was put into another tube and centrifuged. The upper filter was put into the DNA tubes, $100 \mu \mathrm{l}$ DNA-protecting buffer was added and centrifuged. The DNA isolation was completed for PCR analysis.

\section{Genotyping}

Exon 15 of the BRAF gene was amplified by the polymerase chain reaction restriction fragment length (PCRRFL) polymorphism method with the following primers. For PCR-RFLP, a $50 \mu \mathrm{L}$ PCR mixture was composed of extracted DNA. The amplicon size was $130 \mathrm{bp}$.

Primers for BRAF mutation for the first PCR as follows: sense: 5' - TAAAAATAGGTGATTTTGGTCT AGCTGC-3',

antisense: 5'CCAAAAATTTAATCAGTGGAAA AATA-3'. The PCR cycling conditions were as follows; initial denaturation step at $95^{\circ} \mathrm{C}$ for $11 \mathrm{~min}, 30$ cycles of: $95^{\circ} \mathrm{C} 30 \mathrm{~s}, 58^{\circ} \mathrm{C} 30 \mathrm{~s}, 72^{\circ} \mathrm{C} 30 \mathrm{~s}$ and the final elongation for $5 \mathrm{~min}$ at $72{ }^{\circ} \mathrm{C}$. The amplified $130 \mathrm{bp}$ long
PCR products were digested at $37^{\circ} \mathrm{C}$ for $3 \mathrm{~h}$ with $\mathrm{BtsI}$ restriction enzyme and separated by $10 \%$ PAGE for 20 min. The BRAF ${ }^{\mathrm{V} 600 \mathrm{E}}$ mutation had 112 and $18 \mathrm{bp}$ fragments for the AA genotype and 78, 34 and $18 \mathrm{bp}$ for the WT genotype.

Primers for BRAF mutation for the second PCR as follows: sense: F: 5'-TAAAAATAGGTGATTTTGG TCTAGCTGC-3',

antisense: R: 5'AAAAATTTAAGCAGTGGAAA AATAC- $3^{\prime}$. The PCR cycling conditions were as follows; initial denaturation step at $95^{\circ} \mathrm{C}$ for $11 \mathrm{~min}, 30$ cycles of: $95^{\circ} \mathrm{C} 30 \mathrm{~s}, 58^{\circ} \mathrm{C} 30 \mathrm{~s}, 72^{\circ} \mathrm{C} 30 \mathrm{~s}$ and the final elongation for $5 \mathrm{~min}$ at $72^{\circ} \mathrm{C}$. The amplified $224 \mathrm{bp}$ long PCR products were digested at $65^{\circ} \mathrm{C}$ overnight with a TspRI restriction enzyme and separated by $8 \%$ PAGE for $20 \mathrm{~min}$. Finally, samples were stained with silver nitrate and photographed.

\section{Statistical Evaluation}

The statistical analyses were performed using NCSS (Number Cruncher Statistical System) 2007 Statistical Software (Utah, USA) package program. In the evaluation of the data, apart from the descriptive statistical methods (mean, standard deviation), the independent samples T-test was used in comparing pairwise groups, while Chi-Square and Fisher's Exact Test and Odds Ratio were used in evaluating the qualitative data. The results were evaluated at a $\mathrm{p}<0.05$ significance level with a 95\% confidence interval.

\section{RESULTS}

The study population included 72 patients (Female/ Male: 60/12). The cases of this study received the diagnosis of PTMC incidentally. Thyroidectomy was performed on 26 of 72 patients $(36.1 \%)$ due to multinodular goiter and PTMC was diagnosed after thyroidectomy. In the rest of the group with 46 patients (63.8\%), FNAB was performed according to the suspicious features of the nodules in thyroid ultrasonography and PTMC was diagnosed before surgery. The mean follow-up duration of the whole cohort was three years (min: 1 year, max. 5 years). The mean age was $46.3 \pm 11.7$ years (range, 21-68). The mean size of the tumors was $6.7 \pm 2.3 \mathrm{~mm}$ (range, $1-10$ ).

The BRAF ${ }^{\mathrm{V} 600 \mathrm{E}}$ mutation was present in $41.6 \%(30$ of 72) of the patients. The presence of classical variant type $(p=0.046)$, thyroid capsule invasion $(p=0.002)$ and 
TABLE 1. The relationship between BRAF mutation and clinicopathological features

\begin{tabular}{|c|c|c|c|c|c|}
\hline & \multicolumn{2}{|c|}{$\begin{array}{c}\text { BRAF }(+) \\
\text { group }\end{array}$} & \multicolumn{2}{|c|}{$\begin{array}{c}\text { BRAF (-) } \\
\text { group }\end{array}$} & \multirow[t]{2}{*}{$\mathrm{p}$} \\
\hline & $\mathrm{n}$ & $\%$ & $\mathrm{n}$ & $\%$ & \\
\hline Male & 3 & 10.00 & 9 & 21.43 & 0.20 \\
\hline Female & 27 & 90.00 & 33 & 78.57 & \\
\hline Diagnostic age $\leq 45$ & 14 & 46.67 & 12 & 28.57 & 0.11 \\
\hline Diagnostic age $>45$ & 16 & 53.33 & 30 & 71.43 & \\
\hline Follicular variant & 8 & 26.66 & 21 & 50.00 & 0.046 \\
\hline Classical type & 22 & 73.33 & 21 & 50.00 & \\
\hline Tumor diameter $\leq 5 \mathrm{~mm}$ & 8 & 26.67 & 17 & 40.48 & 0.22 \\
\hline Tumor diameter >5 mm & 22 & 73.33 & 25 & 59.52 & \\
\hline Thyroid capsule invasion & 20 & 66.67 & 13 & 30.95 & 0.002 \\
\hline Extrathyroidal invasion & 12 & 40.00 & 11 & 26.19 & 0.21 \\
\hline Lymph node metastasis & 0 & 0 & 3 & 7.14 & 0.13 \\
\hline Multifocality & 9 & 30.00 & 21 & 50.00 & 0.87 \\
\hline Bilaterality & 9 & 30.00 & 9 & 21.43 & 0.40 \\
\hline Absence of tumor capsule & 24 & 80.00 & 19 & 45.24 & 0.003 \\
\hline Hashimoto's thyroiditis & 17 & 56.67 & 16 & 38.10 & 0.11 \\
\hline Found before surgery & 22 & 73.33 & 24 & 51.14 & 0.15 \\
\hline Found after surgery & 8 & 26.66 & 18 & 42.85 & \\
\hline
\end{tabular}

BRAF: B-type Raf.

absence of tumor capsule ( $p=0.003)$ were statistically significantly higher in BRAF $(+)$ group than in BRAF $(-)$ group. The presence of the BRAF mutation in our patients strongly predicted the classical variant type of PTC, thyroid capsule invasion and the absence of tumor capsule (Table 1 ). The mean size of the tumor was $7.1 \pm 1.9$ $\mathrm{mm}$ in the mutated patient group and $6.4 \pm 2.5 \mathrm{~mm}$ in wild type patient group. There was no significant correlation between the BRAF mutation and tumor diameter $(p=0.087)$. The mean age at diagnosis was $43.8 \pm 12.1$ years in BRAF $(+)$ group and $48.2 \pm 11.3$ years in BRAF $(-)$ group. The female sex was dominant in the study population (83.3\%); however, there was no statistically significantly difference in gender with $\mathrm{BRAF}^{\mathrm{V} 600 \mathrm{E}}$ mutation positivity $(p=0.20)$. LNM was present in three cases; all of them were negative for the mutation and were tumors $>5 \mathrm{~mm}$ in diameter. There was only one case with distant metastasis (to lung) that had BRAF wild type mutation and was a tumor $>5 \mathrm{~mm}$ in size. There was no relationship between the BRAF mutation and LNM or distant metastasis in our study population. Total thyroidectomy was performed on 71 patients, while one patient had a
TABLE2. Comparison of the clinicopathological features of the cases found before surgery versus found after surgery

\begin{tabular}{|c|c|c|c|c|c|}
\hline & \multicolumn{2}{|c|}{$\begin{array}{c}\text { Found before } \\
\text { surgery }\end{array}$} & \multicolumn{2}{|c|}{$\begin{array}{c}\text { Found after } \\
\text { surgery }\end{array}$} & \multirow[t]{2}{*}{$\mathrm{p}$} \\
\hline & $\mathrm{n}$ & $\%$ & $\mathrm{n}$ & $\%$ & \\
\hline Male & 7 & 15.00 & 5 & 19.00 & 0.66 \\
\hline Female & 39 & 85.00 & 21 & 81.00 & \\
\hline BRAF mutation (+) & 22 & 47.82 & 8 & 30.77 & 0.15 \\
\hline BRAF mutation (-) & 24 & 52.17 & 18 & 69.23 & \\
\hline Thyroid capsule invasion & 25 & 54.34 & 8 & 30.77 & 0.045 \\
\hline Bilaterality & 11 & 23.90 & 7 & 26.90 & 0.77 \\
\hline Multifocality & 17 & 36.90 & 13 & 50.00 & 0.28 \\
\hline Absence of tumor capsule & 30 & 65.20 & 13 & 50.00 & 0.20 \\
\hline Extrathyroidal invasion & 17 & 36.90 & 6 & 23.10 & 0.22 \\
\hline Hashimoto's thyroiditis & 24 & 52.10 & 9 & 34.60 & 0.15 \\
\hline Tumor diameter >5 mm & 35 & 76.10 & 12 & 46.10 & 0.010 \\
\hline
\end{tabular}

lobectomy. One patient who had received radiation therapy in the neck region due to nasopharyngeal cancer, and one patient who was working as a radiology technician, were both negative for the mutation. Seven patients (9.7\%) had thyroid cancer history in their family (3 patients with mutated, four patients with wild type BRAF). Forty-nine patients received RAI ablation therapy due to thyroid capsule invasion, ETE, lymph node involvement and distant metastasis (21 patients with mutated, 28 patients with wild type BRAF). The stage distribution was as follows: all cases positive for the BRAF mutation were in stage 1 . Four cases negative for the mutation: two of them were in stage 2 ; two of them were in stage 3 . There was no relationship between BRAF mutation presence and advanced stage. The mean TSH value $(\mathrm{mIU} / \mathrm{L})$ was $1.4 \pm 1.2$ in BRAF $(-)$ patient group and $1.6 \pm 0.98$ in BRAF $(+)$ patient group. In summary, there was no significant correlation with age, gender, multifocality, bilaterality, ETE, presence of Hashimoto's thyroiditis, and TSH value between mutated and wild-type patient groups. All of the patients had adequate follow-up information. No disease-specific mortality or regional or distant recurrences were demonstrated during the follow-up period.

The patients were divided into two groups as follows: the first group who were diagnosed after surgery included 26 patients, the second group who were diagnosed before surgery, included 46 patients. When the two groups were compared, the second group was more 
TABLE 3. Comparison of the clinicopathological features of BRAF positive cases, found before surgery versus found after surgery

\begin{tabular}{|c|c|c|c|c|c|}
\hline & \multirow{2}{*}{\multicolumn{2}{|c|}{$\begin{array}{l}\begin{array}{l}\text { Found before } \\
\text { surgery }\end{array} \\
\begin{array}{c}\text { BRAF (+) } \\
\text { group }\end{array}\end{array}$}} & \multirow{2}{*}{\multicolumn{2}{|c|}{$\begin{array}{c}\begin{array}{c}\text { Found after } \\
\text { surgery }\end{array} \\
\text { BRAF (+) } \\
\text { group }\end{array}$}} & \multirow{3}{*}{$\mathrm{p}$} \\
\hline & & & & & \\
\hline & $\mathrm{n}$ & $\%$ & $\mathrm{n}$ & $\%$ & \\
\hline Male & 2 & 9.90 & 1 & 12.50 & 0.78 \\
\hline Female & 20 & 90.10 & 7 & 87.50 & \\
\hline Thyroid capsule invasion & 15 & 68.10 & 5 & 62.50 & 0.77 \\
\hline Bilaterality & 7 & 31.80 & 2 & 25.00 & 0.71 \\
\hline Multifocality & 7 & 31.80 & 2 & 25.00 & 0.71 \\
\hline Absence of tumor capsule & 18 & 81.90 & 6 & 75.00 & 0.67 \\
\hline Extrathyroidal invasion & 8 & 36.40 & 4 & 50.00 & 0.50 \\
\hline Hashimoto's thyroiditis & 13 & 59.10 & 4 & 50.00 & 0.65 \\
\hline Diagnostic age $\leq 45$ & 13 & 59.10 & 1 & 12.50 & 0.023 \\
\hline Tumor diameter $>5 \mathrm{~mm}$ & 16 & 72.00 & 6 & 75.00 & 0.90 \\
\hline
\end{tabular}

BRAF: B-type Raf.

prone to have thyroid capsule invasion $(p=0.045)$ and larger tumor size $(\mathrm{p}=0.010)$ (Table 2$)$.

BRAF ( + ) patients were compared between the two groups. Patients had similar tumor characteristics; however, diagnostic age was statistically significantly lower in patients discovered before surgery $(\mathrm{p}=0.023)$ (Table 3$)$.

\section{DISCUSSION}

In recent years, the incidence of thyroid cancer has rapidly increased worldwide [2]. This increase is mostly a result of the identification of smaller thyroid tumors due to increased use of high-resolution thyroid ultrasonography and imaging for non-thyroid related conditions [34]. PTCs equal to or less than $1 \mathrm{~cm}$ are classified as PTMCs. A small percentage of patients with PTMC has reported presenting with high-risk features (ETE, LNM), even clinically significant distant metastasis [810]. They may require more aggressive treatment. The activating somatic point mutation in the BRAF gene is specific to PTCs and it plays the main role in tumorigenesis and its progression [35]. The BRAF mutation may identify aggressiveness in patients with PTMC. Therefore, over the past decade, BRAF mutation has been widely studied in PTMCs.
Advances in ultrasonographic screening and USGguided FNAB have allowed more PTMCs to be detected in their early stages $[3,35]$. PTMC may be found nonincidentally or incidentally. Incidental microcarcinoma is detected following surgery or neck ultrasonography for benign thyroid diseases or nonrelated thyroid pathologies [36]. Nonincidental microcarcinoma is found on clinical presentation with local or distant metastasis [36]. PTMC determined incidentally has a better prognosis and lower recurrence risk than that determined nonincidentally [37]. We found that the presence of the BRAF mutation strongly predicted the thyroid capsule invasion and the absence of tumor capsule. The presence of a capsule within the tumor is a major factor for determining the prognosis, and the encapsulated tumors do not tend to have LNM $[38,39]$. A meta-analysis showed that the BRAF mutation was associated with ETE and the absence of tumor capsule [40]. PTMC with thyroid capsule invasion may be more likely to have an increased tendency of having ETE [41]. Many studies found a significant association between BRAF mutation and ETE $[10,14,27,28,31$, 40, 42-50]. LNM and ETE were predictors of persistent/recurrent disease [49]. BRAF ${ }^{\mathrm{V} 600 \mathrm{E}}$ mutation might be a molecular marker of tumor invasiveness and this relationship was independent of tumor size [10, 40]. A recent multicenter study that included 743 patients reported that $\mathrm{BRAF}^{\mathrm{V} 600 \mathrm{E}}$ mutation differentiated the recurrence risk of PTMC, particularly low-risk PTMC [51]. In contrast, other studies reported that this mutation was not correlated with LNM [30, 31, 52, 53]. We reported no recurrence during the follow-up period in our study population; this might be associated with that all of the patients with BRAF mutation underwent total or near-total thyroidectomy. In addition, the whole cohort was discovered incidentally and $70 \%$ of the patients with BRAF mutation received RAI ablation therapy. The follow-up period might be too short a time to determine the recurrence rate and prognosis.

Many studies reported that a significant association existed between BRAF mutation and multifocality [14, $28,31,43,45,46]$. Lin et al. found that multifocality can be associated with LNM in PTMCs [54]. In our study, multifocality did not significantly differ between the mutated and non-mutated groups. Kebebew et al. found that mutation frequency increased in parallel with age [55]. Six studies were analyzed for the association between BRAF mutation and age [10, 31, 41, 44-46], and found no significant association. In our study, there was 
no significant association between age and the BRAF mutation. There was no significant association between BRAF mutation and male gender in many studies [10, $14,28,31,41,43-47,50]$, except for two $[29,56]$. We found no relation between the BRAF mutation and the male gender. This may be related to the low number of male cases in our study. Most of the current staging systems use $5 \mathrm{~mm}$ as the cut-off value to differentiate between low and high-risk PTMC [41]. Tumor size larger than $5 \mathrm{~mm}$ was found to be associated with recurrent PTMC [57]. In two studies, there was a significant association between BRAF mutation and tumor size being higher than $5 \mathrm{~mm}[43,44]$, whereas another study showed no difference like our results [58]. Surprisingly, we found that tumors negative for the mutation, but were $>5 \mathrm{~mm}$ in size had lymph node or distant metastasis. The relationship between the BRAF mutation and tumor size remains controversial. This study found the $\mathrm{BRAF}^{\mathrm{V} 600 \mathrm{E}}$ mutation prevalence of $41.6 \%$ was similar to earlier studies $[25,28,50]$. However, the mutation frequency was relatively high in Korean patients [31]. This may be related to geographical differences.

BRAF $^{\mathrm{V} 600 \mathrm{E}}$ mutation-positive and negative PTCs have distinctive histology. Compared with the follicular variant, classical and tall cell variants of PTCs have a higher $\mathrm{BRAF}^{\mathrm{V} 600 \mathrm{E}}$ mutation rate $[30,59]$. Three studies, including 243 patients, analyzed the association of BRAF mutation and tall cell variant (TCV) of PTMC (TCVPTMC). They found a significant association between BRAF mutation and TCVPTMC $[10,44,47]$. There was no patient with TCV in our study population. We found a significant association between the BRAF mutation and the classical variant.

Multiple studies have reported that PTC, along with Hashimoto's thyroiditis (HT), had more favorable clinicopathological features and a better prognosis than those without HT [60]. It has been reported that HT is a potential protective factor for PTC, regardless of the $\mathrm{BRAF}^{\mathrm{V} 600 \mathrm{E}}$ mutation [61]. However, the underlying molecular mechanism of the association between HT and PTC is still unknown. The theory of 'tumor defenseinduced autoimmunity' may explain the coexistence of HT and PTC [62]. The immune cell infiltration into the thyroid is believed to be an ongoing antitumor immune response, which leads to a better prognosis among PTC patients [62]. Three studies reported the association between BRAF mutation and concomitant HT [10, $41,46]$. However, other studies identified contradictory results [63]. In this study, no significant association was found between BRAF mutation and concomitant HT. This outcome may be due to the small study population. The relationship between BRAF mutation and chronic thyroiditis in PTMC requires further assessment.

A study from Turkey found that PTMCs harboring BRAF mutation had a more aggressive behavior [28], although conflicting findings were reported in another study [33]. The difference of our study was that we evaluated the BRAF mutation in incidental PTMCs. Incidental microcarcinomas have lower recurrence rate than nonincidental microcarcinomas [37]. Nevertheless, tumors positive for the mutation were more prone to spread the thyroid capsule in our study population.

We recognize some of the limitations of this study. First, it is a retrospective single-center study. Second, the sample size is small. The limited number of cases may mask the relationship between BRAF mutation and prognostic factors. Third, we have not long term follow-up time.

\section{Conclusion}

This report confirmed that BRAF mutation status was not associated with recurrences and poorer outcomes in a 3-year follow-up period in our study population. However, tumors positive for the mutation had more invasive behavior. There have been conflicting data on the management and treatment of PTMCs among the physicians. Currently, many studies discussed how BRAF mutation influences surgical type for PTMC patients. We believe that BRAF mutation screening of FNAB specimens preoperatively may give a guidance to determine the initial surgical approach. For better understanding of this issue, future prospective studies are needed with a long follow up period and larger patient groups.

Consent: Our study is retrospective study, and all of our patients agreed to us using their medical information.

Ethics Committee Approval: The Kocaeli University Clinical Research Ethics Committee granted approval for this study (date: 20.11.2012 number: KOU KAEK 2012/130).

Conflict of Interest: No conflict of interest was declared by the authors.

Financial Disclosure: This research was supported by research funds from Kocaeli University Faculty of Medicine.

Authorship Contributions: Concept - HS; Design - NU; Supervision - DY; Materials - NU; Data collection and/or processing - HS; Analysis and/or interpretation - NU; Literature review - DY; Writing - HS; Critical review - DY. 


\section{REFERENCES}

1. Mazzaferri EL, Jhiang SM. Long-term impact of initial surgical and medical therapy on papillary and follicular thyroid cancer. Am J Med 1994;97:418-28. [CrossRef]

2. Ries LAG, Melbert D, Krapcho M, Stinchcomb DG, Howlader N, Horner MJ, editors. SEER Cancer Statistics Review, 1975-2005. National Cancer Institute; 2008.

3. Yokozawa T, Miyauchi A, Kuma K, Sugawara M. Accurate and simple method of diagnosing thyroid nodules the modified technique of ultrasound-guided fine needle aspiration biopsy. Thyroid 1995;5:141-5.

4. Xing M. BRAF mutation in papillary thyroid microcarcinoma: the promise of better risk management. Ann Surg Oncol 2009;16:801-3.

5. Sobin LH, Wittekind C. TNM Classification of Malignant Tumours, $6^{\text {th }}$ ed. John Wiley $\&$ Sons Inc; 2002. [CrossRef]

6. Yamashita $\mathrm{H}$, Noguchi $\mathrm{S}$, Watanabe S, Uchino S, Kawamoto H, Toda $\mathrm{M}$, et al. Thyroid cancer associated with adenomatous goiter: an analysis of the incidence and clinical factors. Surg Today 1997;27:495-9.

7. de Matos PS, Ferreira AP, Ward LS. Prevalence of papillary microcarcinoma of the thyroid in Brazilian autopsy and surgical series. Endocr Pathol 2006;17:165-73. [CrossRef]

8. Chow SM, Law SC, Chan JK, Au SK, Yau S, Lau WH. Papillary microcarcinoma of the thyroid-Prognostic significance of lymph node metastasis and multifocality. Cancer 2003;98:31-40. [CrossRef]

9. John AM, Jacob PM, Oommen R, Nair S, Nair A, Rajaratnam S. Our experience with papillary thyroid microcancer. Indian J Endocrinol Metab 2014;18:410-3. [CrossRef]

10. Lee X, Gao M, Ji Y, Yu Y, Feng Y, Li Y, et al. Analysis of differential $\operatorname{BRAF}\left({ }^{\mathrm{V} 600 \mathrm{E}}\right)$ mutational status in high aggressive papillary thyroid microcarcinoma. Ann Surg Oncol 2009;16:240-5. [CrossRef]

11. Mazzaferri EL. Managing small thyroid cancers. JAMA 2006;295:2179-82. [CrossRef]

12. Mazzaferri EL. Management of low-risk differentiated thyroid cancer. Endocr Pract 2007;13:498-512. [CrossRef]

13. Hay ID. Management of patients with low-risk papillary thyroid carcinoma. Endocr Pract 2007;13:521-33. [CrossRef]

14. Lin KL, Wang OC, Zhang XH, Dai XX, Hu XQ, Qu JM. The BRAF mutation is predictive of aggressive clinicopathological characteristics in papillary thyroid microcarcinoma. Ann Surg Oncol 2010;17:3294300. [CrossRef]

15. Yamashita H, Noguchi S, Murakami N, Toda M, Uchino S, Watanabe $\mathrm{S}$, Kawamoto H. Extracapsular invasion of lymph node metastasis. A good indicator of disease recurrence and poor prognosis in patients with thyroid microcarcinoma. Cancer 1999;86:842-9. [CrossRef]

16. Sugitani I, Fujimoto Y. Symptomatic versus asymptomatic papillary thyroid microcarcinoma: a retrospective analysis of surgical outcome and prognostic factors. Endocr J 1999;46:209-16. [CrossRef]

17. Reddy RM, Grigsby PW, Moley JF, Hall BL. Lymph node metastases in differentiated thyroid cancer under $2 \mathrm{~cm}$. Surgery 2006;140:1050-5.

18. Cappelli C, Castellano M, Braga M, Gandossi E, Pirola I, De Martino E, et al. Aggressiveness and outcome of papillary thyroid carcinoma (PTC) versus microcarcinoma (PMC): a mono-institutional experience. J Surg Oncol 2007;95:555-60. [CrossRef]

19. Ito Y, Miyauchi A, Inoue H, Fukushima M, Kihara M, Higashiyama $\mathrm{T}$, et al. An observational trial for papillary thyroid microcarcinoma in Japanese patients. World J Surg 2010;34:28-35. [CrossRef]

20. Ito Y, Miyauchi A, Kihara M, Higashiyama T, Kobayashi K, Miya A. Patient age is significantly related to the progression of papillary micro- carcinoma of the thyroid under observation. Thyroid 2014;24:27-34.

21. Sugitani I, Fujimoto Y, Yamada K. Association between serum thyrotropin concentration and growth of asymptomatic papillary thyroid microcarcinoma. World J Surg 2014;38:673-8. [CrossRef]

22. Sugitani I, Toda K, Yamada K, Yamamoto N, Ikenaga M, Fujimoto Y. Three distinctly different kinds of papillary thyroid microcarcinoma should be recognized: our treatment strategies and outcomes. World J Surg 2010;34:1222-31. [CrossRef]

23. Kimura ET, Nikiforova MN, Zhu Z, Knauf JA, Nikiforov YE, Fagin JA. High prevalence of BRAF mutations in thyroid cancer: genetic evidence for constitutive activation of the RET/PTC-RAS-BRAF signaling pathway in papillary thyroid carcinoma. Cancer Res 2003;63:14547.

24. Song YS, Lim JA, Park YJ. Mutation Profile of Well-Differentiated Thyroid Cancer in Asians. Endocrinol Metab (Seoul) 2015;30:25262. [CrossRef]

25. Xing M. BRAF mutation in papillary thyroid cancer: pathogenic role, molecular bases, and clinical implications. Endocr Rev 2007;28:74262. [CrossRef]

26. Xing M, Westra WH, Tufano RP, Cohen Y, Rosenbaum E, Rhoden KJ, et al. BRAF mutation predicts a poorer clinical prognosis for papillary thyroid cancer. J Clin Endocrinol Metab 2005;90:6373-9. [CrossRef]

27. Xing M, Alzahrani AS, Carson KA, Viola D, Elisei R, Bendlova B, et al. Association between BRAF ${ }^{\mathrm{V} 600 \mathrm{E}}$ mutation and mortality in patients with papillary thyroid cancer. JAMA 2013;309:1493-501. [CrossRef]

28. Kurtulmus N, Duren M, Ince U, Cengiz Yakicier M, Peker O, Aydın O, et al. $\mathrm{BRAF}\left({ }^{\mathrm{V} 600 \mathrm{E}}\right)$ mutation in Turkish patients with papillary thyroid cancer: strong correlation with indicators of tumor aggressiveness. Endocrine 2012;42:404-10. [CrossRef]

29. Kim SJ, Lee KE, Myong JP, Park JH, Jeon YK, Min HS, et al. BRAFV600E mutation is associated with tumor aggressiveness in papillary thyroid cancer. World J Surg 2012;36:310-7. [CrossRef]

30. Nikiforova MN, Kimura ET, Gandhi M, Biddinger PW, Knauf JA, Basolo F, et al. BRAF mutations in thyroid tumors are restricted to papillary carcinomas and anaplastic or poorly differentiated carcinomas arising from papillary carcinomas. J Clin Endocrinol Metab 2003;88:5399-404. [CrossRef]

31. Kim TY, Kim WB, Song JY, Rhee YS, Gong G, Cho YM, et al. The BRAF mutation is not associated with poor prognostic factors in Korean patients with conventional papillary thyroid microcarcinoma. Clin Endocrinol (Oxf) 2005;63:588-93. [CrossRef]

32. Ozdemir D, Dagdelen S, Kiratli P, Tuncel M, Erbas B, Erbas T. Changing clinical characteristics of thyroid carcinoma at a single center from Turkey: before and after the Chernobyl disaster. Minerva Endocrinol 2012;37:267-74.

33. Kurt B, Yalçın S, Alagöz E, Karslıŏlu Y, Yigit N, Günal A, et al. The relationship of the BRAF $\left({ }^{\mathrm{V} 600 \mathrm{E}}\right)$ mutation and the established prognostic factors in papillary thyroid carcinomas. Endocr Pathol 2012;23:13540. [CrossRef]

34. Vaccarella S, Dal Maso L, Laversanne M, Bray F, Plummer M, Franceschi $\mathrm{S}$. The Impact of Diagnostic Changes on the Rise in Thyroid Cancer Incidence: A Population-Based Study in Selected High-Resource Countries. Thyroid 2015;25:1127-36. [CrossRef]

35. Ma YJ, Deng XL, Li HQ. BRAF $\left(V^{600} E\right)$ mutation and its association with clinicopathological features of papillary thyroid microcarcinoma: A meta-analysis. J Huazhong Univ Sci Technolog Med Sci 2015;35:591-9. [CrossRef]

36. Slijepcevic N, Zivaljevic V, Marinkovic J, Sipetic S, Diklic A, Paunovic I. Retrospective evaluation of the incidental finding of 403 papillary 
thyroid microcarcinomas in 2466 patients undergoing thyroid surgery for presumed benign thyroid disease. BMC Cancer 2015;15:330.

37. Mehanna H, Al-Maqbili T, Carter B, Martin E, Campain N, Watkinson J, et al. Differences in the recurrence and mortality outcomes rates of incidental and nonincidental papillary thyroid microcarcinoma: a systematic review and meta-analysis of 21329 person-years of follow-up. J Clin Endocrinol Metab 2014;99:2834-43. [CrossRef]

38. Kakudo K, Tang W, Ito Y, Mori I, Nakamura Y, Miyauchi A. Papillary carcinoma of the thyroid in Japan: subclassification of common type and identification of low risk group. J Clin Pathol 2004;57:1041-6.

39. Finkelstein A, Levy GH, Hui P, Prasad A, Virk R, Chhieng DC, et al. Papillary thyroid carcinomas with and without $\mathrm{BRAF}^{\mathrm{V} 600 \mathrm{E}}$ mutations are morphologically distinct. Histopathology 2012;60:1052-9. [CrossRef]

40. Li C, Lee KC, Schneider EB, Zeiger MA. BRAF ${ }^{\mathrm{V} 600 \mathrm{E}}$ mutation and its association with clinicopathological features of papillary thyroid cancer: a meta-analysis. J Clin Endocrinol Metab 2012;97:4559-70. [CrossRef]

41. Ji YF. Clinical and biological characteristics of papillary thyroid microcarcinoma and the association with BRAF mutation. Shanghai: Thesis of Nankai University; 2008.

42. Xing M, Alzahrani AS, Carson KA, Shong YK, Kim TY, Viola D, et al. Association between $\mathrm{BRAF}^{\mathrm{V} 600 \mathrm{E}}$ mutation and recurrence of papillary thyroid cancer. J Clin Oncol 2015;33:42-50. [CrossRef]

43. Kwak JY, Kim EK, Chung WY, Moon HJ, Kim MJ, Choi JR. Association of BRAF ${ }^{\mathrm{V} 600 \mathrm{E}}$ mutation with poor clinical prognostic factors and US features in Korean patients with papillary thyroid microcarcinoma. Radiology 2009;253:854-60. [CrossRef]

44. Virk RK, Van Dyke AL, Finkelstein A, Prasad A, Gibson J, Hui P, et al. BRAF ${ }^{\mathrm{V} 600 \mathrm{E}}$ mutation in papillary thyroid microcarcinoma: a genotype-phenotype correlation. Mod Pathol 2013;26:62-70. [CrossRef]

45. Lupi C, Giannini R, Ugolini C, Proietti A, Berti P, Minuto M, et al. Association of $\mathrm{BRAF}^{\mathrm{V} 600 \mathrm{E}}$ mutation with poor clinicopathological outcomes in 500 consecutive cases of papillary thyroid carcinoma. J Clin Endocrinol Metab 2007;92:4085-90. [CrossRef]

46. Choi SY, Park H, Kang MK, Lee DK, Lee KD, Lee HS, et al. The relationship between the $\mathrm{BRAF}\left({ }^{\mathrm{V} 600 \mathrm{E}}\right)$ mutation in papillary thyroid microcarcinoma and clinicopathologic factors. World J Surg Oncol 2013;11:291. [CrossRef]

47. Rossi ED, Martini M, Capodimonti S, Lombardi CP, Pontecorvi A, Vellone VG, et al. BRAF ( $\left.{ }^{\mathrm{V} 600 \mathrm{E}}\right)$ mutation analysis on liquid-based cytology-processed aspiration biopsies predicts bilaterality and lymph node involvement in papillary thyroid microcarcinoma. Cancer Cytopathol 2013;121:291-7. [CrossRef]

48. Rodolico V, Cabibi D, Pizzolanti G, Richiusa P, Gebbia N, Martorana A, et al. BRAF ${ }^{\mathrm{V} 600 \mathrm{E}}$ mutation and $\mathrm{p} 27 \mathrm{kip} 1$ expression in papillary carcinomas of the thyroid Cancer 2007;110:1218-1226. [CrossRef]

49. Malandrino P, Pellegriti G, Attard M, Violi MA, Giordano C, Sciacca L, et al. Papillary thyroid microcarcinomas: a comparative study of the characteristics and risk factors at presentation in two cancer registries. J Clin Endocrinol Metab 2013;98:1427-34. [CrossRef]

50. Zheng X, Wei S, Han Y, Li Y, Yu Y, Yun X, et al. Papillary microcarcinoma of the thyroid: clinical characteristics and $\mathrm{BRAF}\left({ }^{\mathrm{V} 600 \mathrm{E}}\right)$ mutational status of 977 cases. Ann Surg Oncol 2013;20:2266-73. [CrossRef]

51. Kim KJ, Kim SG, Tan J, Shen X, Viola D, Elisei R, et al. BRAF ${ }^{6000}$ status may facilitate decision-making on active surveillance of low-risk papillary thyroid microcarcinoma. Eur J Cancer 2020;124:161-9.

52. Ito Y, Yoshida H, Maruo R, Morita S, Takano T, Hirokawa M, et al. BRAF mutation in papillary thyroid carcinoma in a Japanese population: its lack of correlation with high-risk clinicopathological features and disease-free survival of patients. Endocr J 2009;56:89-97. [CrossRef]

53. Park VY, Kim EK, Moon HJ, Yoon JH, Kwak JY. The thyroid imaging reporting and data system on US, but not the BRAF ${ }^{\mathrm{V} 600 \mathrm{E}}$ mutation in fine-needle aspirates, is associated with lateral lymph node metastasis in PTC. Medicine 2016;95:e4292. [CrossRef]

54. Lin X, Finkelstein SD, Zhu B, Silverman JF. Molecular analysis of multifocal papillary thyroid carcinoma. J Mol Endocrinol 2008;41:195203. [CrossRef]

55. Kebebew E, Weng J, Bauer J, Ranvier G, Clark OH, Duh QY, et al. The prevalence and prognostic value of BRAF mutation in thyroid cancer. Ann Surg 2007;246:466-70. [CrossRef]

56. Xu X, Quiros RM, Gattuso P, Ain KB, Prinz RA. High prevalence of BRAF gene mutation in papillary thyroid carcinomas and thyroid tumor cell lines. Cancer Res 2003;63:4561-7.

57. Giordano D, Gradoni P, Oretti G, Molina E, Ferri T. Treatment and prognostic factors of papillary thyroid microcarcinoma. Clin Otolaryngol 2010;35:118-24. [CrossRef]

58. Miccoli P, Minuto MN, Ugolini C, Panicucci E, Berti P, Massi M, et al. Intrathyroidal differentiated thyroid carcinoma: tumor size-based surgical concepts. World J Surg 2007;31:888-94. [CrossRef]

59. Trovisco V, Vieira de Castro I, Soares P, Máximo V, Silva P, Magalhães J, et al. BRAF mutations are associated with some histological types of papillary thyroid carcinoma. J Pathol 2004;202:247-51. [CrossRef]

60. Moon S, Chung HS, Yu JM, Yoo HJ, Park JH, Kim DS, et al. Associations between Hashimoto Thyroiditis and Clinical Outcomes of Papillary Thyroid Cancer: A Meta-Analysis of Observational Studies. Endocrinol Metab (Seoul) 2018;33:473-84. [CrossRef]

61. Kim SJ, Myong JP, Jee HG, Chai YJ, Choi JY, Min HS, et al. Combined effect of Hashimoto's thyroiditis and $\mathrm{BRAF}\left({ }^{\mathrm{V} 600 \mathrm{E}}\right)$ mutation status on aggressiveness in papillary thyroid cancer. Head Neck 2016;38:95-101.

62. Ehlers M, Schott M. Hashimoto's thyroiditis and papillary thyroid cancer: are they immunologically linked? Trends Endocrinol Metab 2014;25:656-64. [CrossRef]

63. Matesa-Anić D, Matesa N, Dabelić N, Kusić Z. Coexistence of papillary carcinoma and Hashimoto's thyroiditis. Acta Clin Croat 2009;48:9-12. 